\title{
Healthcare Layoffs During the COVID-19 Pandemic
}

Despite overcrowding of the ICUs with patients infected with coronavirus (COVID-19, SARS-CoV-2), hospitals have halted or downsized other operations. Phoenix-based Banner Health, which is Arizona's largest private employer, will impose "short-term" furloughs and pay cuts for some employees (1). Other major hospitals and hospital systems including the Mayo Clinic Arizona, Dignity Health, Tucson Medical Center and Carondelet have announced similar cost-cutting reductions. Banner Health, which has approximately 43,000 employees in Arizona, is starting the furloughs this week. The nonprofit company anticipates that the measures will affect $5 \%$ to $7 \%$ of its workforce, or up to 3,000 Arizona employees. The company says the furloughs are temporary and employees will be eligible for unemployment benefits, including an extra $\$ 600$ per week provided by Arizona via the federal CARES Act. All senior leaders, including senior vice presidents, presidents, vice presidents and CEOs, will take up to a $20 \%$ reduction in pay beginning in May, Banner said. The company will pause hiring for most non-clinical, non-revenue-generating positions across the organization. This includes newly created jobs as well as vacant roles in the corporate office and facilities. The company will continue to post and recruit for positions that are essential to meet the needs of COVID19.

An analysis by the Arizona Hospital and Healthcare Association shows Arizona hospitals are reporting revenue losses of $30 \%$ to $40 \%$ because of the cancellation of elective procedures and a reduction in emergency department visits. Hospitals had an operating margin, the difference between revenues and expenses, that averaged $2.7 \%$ in 2016 (2). The hospital association has asked Arizona's governor, Doug Ducey, to relax his executive orders on halting elective surgeries and on expanding hospital bed capacity, citing recent modeling projections that indicate Arizona will not be as hard-hit by the disease as previously was predicted.

It is unclear how other healthcare organizations other than hospitals are managing during the COVID-19 pandemic. Our small pulmonary practice has been shut down since mid-March although we are doing some telemedicine. Yet compared to the large healthcare systems, we have managed to retain all our employees at a full-time basis as of today. Our group did apply for a small business loan to the Federal government which was denied.

Richard A. Robbins, MD Editor, SWJPCC

\section{References}

1. Innes S. Banner Health, Arizona's largest health system, to implement pay cuts and furloughs. Arizona Republic. April 20, 2020. Available at: https://www.azcentral.com/story/money/business/health/2020/04/20/banner-health- 
implement-pay-cuts-and-furloughs-arizona-coronavirus-covid-19/5165992002/ (accessed 4/21/20).

2. Moody's Investors Service. Moody's: preliminary FY 2016 US NFP hospital medians edge lower on revenue, expense pressure. Moody's. 16 May 2017. https://www.moodys.com/research/Moodys-Preliminary-FY-2016-US-NFPhospital-medians-edge-lower--PR 366813 Accessed 4/21/20. 